\title{
A COMPARATIVE STUDY OF CLINICAL EFFICACY AND ECG CHANGES WITH LITHIUM CARBONATE VERSUS VERAPAMIL IN PATIENTS OF ACUTE MANIA
}

\author{
Gurvinder Pal Singh ${ }^{1}$, Mukhtiar Singh ${ }^{2}$, Ashish Puri ${ }^{3}$ \\ ${ }_{1}^{1}$ Associate Professor, Department of Psychiatry, GMC, Chandigarh, Punjab, India. \\ ${ }^{2}$ Associate Professor, Department of Pharmacology, MMMC \& H, Solan, Himachal Pradesh, India. \\ ${ }^{3}$ Assistant Professor, Department of Pharmacology, DYSPGMC, Nahan, Himachal Pradesh, India.
}

ABSTRACT

\section{BACKGROUND}

Verapamil has been studied as an alternative to lithium for treatment of acute mania and its prophylaxis. This study was undertaken to compare the efficacy and ECG changes in patients receiving lithium and patients receiving verapamil for treatment of acute mania.

\section{MATERIALS AND METHODS}

50 subjects of acute mania were randomized to receive lithium (n=25) Group A and verapamil (n=25) Group B in 4 weeks double blind parallel group comparative study. Both groups were homogeneous with regard to demographic and disease variables. After giving first dose of verapamil and lithium, ECGs were recorded at base line, 7 th, and $28^{\text {th }}$ days of trial and subjected to unpaired and paired t-test. $\mathrm{p}<0.05$ was considered statistically significant. Efficacy parameters were recorded 48 hourly during first week and twice a week thereafter. Ordinal data was analysed by non-parametric and true interval by parametric tests. Probability test used to compare patients and disease characteristics.

\section{RESULTS}

Both groups improved significantly ( $>00.05$ ) from baseline over a period of 28 days as per Bech-Raefelson Mania Rating Scale (BRMRS) score and attendants' assessment relief report and both groups showed no major differences in ECG changes during trial. However, Verapamil produces more bradycardia and $\mathrm{T}$ wave depression.

\section{CONCLUSION}

Verapamil is equally effective alternative to lithium for control of acute mania over a short period. However, baseline and periodic ECG monitoring is required to avoid cardiac toxicity with verapamil. Therefore, it is suggested to compare safety and efficacy by conducting long term and large sample size studies.

\section{KEY WORDS}

Bradycardia, ECG, Lithium, Mania, Verapamil

HOW TO CITE THIS ARTICLE: Singh GP, Singh M, Puri A. A comparative study of clinical efficacy and ECG changes with lithium carbonate versus verapamil in patients of acute mania. J. Evolution Med. Dent. Sci. 2019;8(11):788-792, DOI: $10.14260 /$ jemds/2019/173

\section{BACKGROUND}

Manic episode is characterised by intense elation of mood along with hyperactivity, less need for sleep, flight of thoughts and easy distractibility of mind.[1] Manic episodes are generally the part of bipolar disorders and the manic attacks often last for short duration. ${ }^{[2]}$ The incidence of mania in old age patients is 5-10\%.[3] During the past many years different medications have been tried for acute mania. Lithium has been utilized for the treatment of acute bipolar affective disorders for more than 50 years. Lithium is associated with a number of cardiovascular side effects in humans when used for treatment of acute mania such as decrease in heart rate, fall in blood pressure and cardiac arrhythmias. The fall in blood pressure due to lithium is not clinically significant.

'Financial or Other Competing Interest': None.

Submission 02-02-2019, Peer Review 05-03-2019,

Acceptance 08-03-2019, Published 18-03-2019.

Corresponding Author:

Dr. Mukhtiar Singh,

H. No. 46/23, Passey Road,

Patiala,

Punjab, India.

E-mail:drmsvirk@gmail.com

DOI: 10.14260/jemds/2019/173

\section{(c) (i) $\$$}

Electrocardiographic changes are also produced with the use of lithium as it causes depression of SA node, dysfunction of $\mathrm{AV}$ node, $\mathrm{T}$ wave flattening and reversible premature ventricular contractions (PVCs). The ions of lithium $\left(\mathrm{Li}^{+}\right)$penetrate into cardiac muscle fibres and cause depletion of potassium $\left(\mathrm{K}^{+}\right)$ions from them and it may be responsible for $\mathrm{T}$-wave changes. Lithium also produces metabolic changes in cardiac muscle fibers. ${ }^{[4]}$ The side effects of Lithium, particularly tremors and polyuria can cause considerable discomfort to the patients and also possible long term adverse effects on thyroid gland and on kidney are the source of continuing concern.[5] Other side effects of Lithium are nausea, vomiting, diarrhoea, GI pain/distress, headache, confusion, blurred vision and hyperreflexia. The need for regular monitoring of serum Lithium levels, their maintenance within narrow therapeutic range, problems of compliance and the danger of accidental or suicidal overdose which may further complicate long term treatment and in severe toxicity cases coma and death may occur. Verapamil, a primarily cardiovascular drug is a calcium channel blocker, has been investigated in the treatment of hypomanic patients and patients not responding to therapy with lithium and mood stabilizing drugs or in those where these are contraindicated. Therefore, Verapamil may be useful as a short term or long-term drug therapy in the management of 
acute mania. ${ }^{[3,6]}$ Verapamil is usually well tolerated and possesses antimanic effects comparable to Lithium. Goodnick used Verapamil in 3 pregnant females with bipolar affective disorder and reported good control of mania with no adverse effects related to pregnancy and child birth.[7] A study on verapamil was conducted by Dubovsky SL and Randall Buzan as an effective alternative in the treatment of mania. ${ }^{[8]}$ The cardiovascular effects of verapamil such as decrease in heart rate due to $\mathrm{SA}$ node depression, $\mathrm{AV}$ nodal depression and $\mathrm{A}-\mathrm{V}$ block etc. by depressing $\mathrm{Ca}^{2+}$ mediated depolarization are well documented. Hence in both the groups comparison of ECG changes and parameters of efficacy with these two drugs is worthwhile to evaluate usefulness of verapamil in the treatment of acute mania.

\section{Objectives}

Objectives of the study were to compare the effects of Lithium carbonate and verapamil given separately on i) clinical efficacy and ii) ECG changes in patients of acute mania.

\section{MATERIALS AND METHODS}

50 patients of bipolar affective disorders fulfilling the inclusion and exclusion criteria were taken in Psychiatric department of Govt. Medical College and Rajindra Hospital, Patiala, Punjab in year 1996-1997. The detailed clinical history, particulars, socioeconomic status and general physical examination of patients were recorded on the patient's proforma. This study was approved by the institutional ethical committee. An informed consent was taken on prescribed proforma from attendant of each patient in writing before enrolling in the study following ICMR guidelines. They were randomly allocated to group A $(n=25)$ and group B $(n=25)$. Group A patients were put on lithium carbonate and group B on verapamil. The investigator was not aware of the therapy given to the patients and treatment codes of all the patients were kept confidential.

\section{Inclusion Criteria}

1. Manic episode patients were confirmed according to ICD 10 criteria.

2. Subjects having score $\geq 10$ on Bech-Raefelson Mania Rating Scale (BRMRS) were included.

3. Age of patients should be between 18-50 years.

\section{Exclusion Criteria}

1. Subjects having history of seizers, drug abusers, mentally retarded patients and patients who had treated with electroconvulsive therapy for the present or the previous manic episode.

2. Subjects taking treatment for other concomitant diseases.

3. Manic women who were planning for pregnancy, lactating mothers and pregnant women.

\section{Design}

Randomized, Controlled, double blind and parallel group study of 28 days' period conducted at Govt. Medical College and Rajindra Hospital Patiala.

1. Efficacy comparison: Efficacy parameters were recorded according to:

a. BRMRS score in both the groups with trial medication on days $1,3,5,7,10,13,17,21,28$.

b. Patient-Attendants' assessment of relief report on day 14 and 28.
2. ECG changes comparison: A twelve lead ECG of all patients in lying down position taken at baseline, after 1 week and after $4^{\text {th }}$ week of study period in both the groups with emphasis on rhythm, heart rate, PR interval, QTc interval, QRS complex, QRS axis, ST segment, Uwave, P-wave and T-wave. These parameters of ECG changes were compared in both the groups. However, in uncooperative patients baseline ECG was recorded only when they became cooperative.

\section{Doses of The Drug}

Lithium Carbonate

- $\quad 300 \mathrm{mg}$ TDS for 5 days.

- Then its dose was adjusted to keep its plasma concentration within therapeutic range (0.6-1.2 mEq/L)

\section{Verapamil}

- $\quad$ On $1^{\text {st }}$ day- $80 \mathrm{mg}$ BD.

- $\quad$ On $2^{\text {nd }} \& 3^{\text {rd }}$ day- $80 \mathrm{mg}$ TDS.

- Then $80 \mathrm{mg}$ QID on $4^{\text {th }}$ day onwards.

The trial of medication in both the groups started according to the dose schedule as mentioned above. All the patients who were cooperative were ensured to get their ECGs done at baseline on the $1^{\text {st }}$ day of trial. Subsequent doses of verapamil were administered only if the patients did not suffer from any cardiovascular effects of the drug. Haloperidol medication was administered IM/IV or orally to the patients who were agitated and non-cooperative as a rescue medicine and to the patients when there was a difficulty in managing the acute manic symptoms and tablet trihexyphenidyl $2 \mathrm{mg}$ thrice a day was given in case extra pyramidal symptoms appear due to haloperidol. Serum Lithium levels were estimated by flame photometric method.[9] Further ECGs were done after $7^{\text {th }}$ day and $28^{\text {th }}$ day of trial medication in both the groups. Efficacy parameter data and ECG changes data were collected and put in tables as mean \pm standard deviation in both the groups.

\section{Statistical analysis}

Non parametric test was performed for nominal and ordinal variable and for continuous variable parametric test was done. Chi-square test was used for ordinal data in two groups. Independent t-test was used for comparing baseline data in which variable have two groups. Paired t-test was performed for continuous variable which came from same population at two different time points. Level of significance is considered at $5 \%$.

RESULTS

\begin{tabular}{|c|c|c|c|}
\hline $\begin{array}{c}\text { Patient } \\
\text { Characteristic }\end{array}$ & $\begin{array}{c}\text { Group A } \\
\text { (n-25) }\end{array}$ & $\begin{array}{c}\text { Group B } \\
\text { (n-25) }\end{array}$ & Significance \\
\hline Age (Years) & Median 30 & Median 30 & $p>0.05 \mathrm{NS}$ \\
\hline Sex & $\begin{array}{c}\text { Males } 18 \\
\text { Females-7 }\end{array}$ & $\begin{array}{c}\text { Males } 20 \\
\text { Females-5 }\end{array}$ & $p>0.05$ NS \\
\hline $\begin{array}{l}\text { Marital } \\
\text { Status }\end{array}$ & $\begin{array}{c}\text { Married } 19 \\
\text { Unmarried } \\
6\end{array}$ & $\begin{array}{c}\text { Married } 17 \\
\text { Unmarried } 8\end{array}$ & $p>0.05$ NS \\
\hline Rural/ Urban & $\begin{array}{c}\text { Rural } 10 \\
\text { Urban } 15 \\
\end{array}$ & $\begin{array}{c}\text { Rural } 11 \\
\text { Urban } 14 \\
\end{array}$ & $p>0.05$ NS \\
\hline Literacy & $\begin{array}{c}\text { Illiterate } 13 \\
\text { Literate } 12\end{array}$ & $\begin{array}{c}\text { Illiterate } 15 \\
\text { Literate } 10\end{array}$ & $p>0.05$ NS \\
\hline
\end{tabular}


The features of all the patients in both the groups; like age, sex, literacy, rural/urban population and marital status were identical as shown in Table- 1 . Table- 1 also shows no statistically significant difference $(p>0.05)$ in age, sex, literacy, Rural/urban population and marital status. Chisquare test was used to get $P$ value.

\begin{tabular}{|c|c|c|c|c|}
\hline \multirow{3}{*}{$\begin{array}{c}\text { Group } \\
\text { A }\end{array}$} & Heart Rate & Day 1 & Day 7 & Day 28 \\
\cline { 2 - 5 } & Mean \pm S.D. & $78.8 \pm 3.15$ & $73.1 \pm 2.5$ & $70.6 \pm 2.7$ \\
\cline { 2 - 5 } & Range & $71-93$ & $60-88$ & $60-88$ \\
\hline \multirow{3}{*}{$\begin{array}{c}\text { Group } \\
\text { B }\end{array}$} & Heart rate & Day 1 & Day 7 & Day 28 \\
\cline { 2 - 5 } & Mean \pm S.D. & $82.8 \pm 3.2$ & $76.2 \pm 2.9$ & $66.6 \pm 2.1$ \\
\cline { 2 - 5 } & Range & $60-107$ & $48-100$ & $42-83$ \\
\hline \multicolumn{4}{|c|}{ Table 2. Heart Rate in Group A and Group B During Trial } \\
\hline
\end{tabular}

Table- 2 shows the mean values of heart rate at base line, on $7^{\text {th }}$ day and on $28^{\text {th }}$ day of trial medication in both the groups (A and B) as 78.8 $\pm 3.15,73.1 \pm 2.5,70.6 \pm 2.7$ and $82.8 \pm 3.2,76.2 \pm 2.9,66.6 \pm 2.1$ respectively. The decrease in heart rate on $7^{\text {th }}$ day was $7.2 \%$ and on $28^{\text {th }}$ day it was $10.4 \%$. The value $10.4 \%$ was statistically significant $(p<0.05)$ in group $\mathrm{A}$. The decrease in heart rate in group B patients on 7 th day $7.97 \%$ and on $28^{\text {th }}$ day $19.6 \%$. The value $19.6 \%$ was statistically significant $(\mathrm{p}<0.05)$ in group B. These observations show that there was greater decrease in heart rate in group B patients on $28^{\text {th }}$ day of trial.

\begin{tabular}{|c|c|c|c|c|}
\hline \multirow{4}{*}{$\begin{array}{c}\text { Group } \\
\text { A }\end{array}$} & PR Interval & Day 1 & Day 7 & Day 28 \\
\hline & Mean \pm S.D. & $\begin{array}{c}0.154 \pm \\
0.0078\end{array}$ & $\begin{array}{c}0.1632 \pm \\
0.0065\end{array}$ & $\begin{array}{c}0.156 \pm \\
0.0516\end{array}$ \\
\hline & Range & $0.06-0.20$ & $0.12-0.20$ & $0.12-0.20$ \\
\hline & $\begin{array}{l}\text { Percentage } \\
\text { Increase }\end{array}$ & & 5.97 & 1.30 \\
\hline \multirow{4}{*}{$\begin{array}{c}\text { Group } \\
\text { B }\end{array}$} & PR interval & Day 1 & Day 7 & Day 28 \\
\hline & Mean \pm S.D. & $\begin{array}{c}0.165 \pm \\
0.0123\end{array}$ & $\begin{array}{l}0.168 \pm \\
0.0065\end{array}$ & $\begin{array}{c}0.1744 \pm \\
0.0056\end{array}$ \\
\hline & Range & $0.08-0.20$ & $0.08-0.20$ & $0.12-0.20$ \\
\hline & $\begin{array}{l}\text { Percentage } \\
\text { Increase }\end{array}$ & & 1.8 & 5.7 \\
\hline
\end{tabular}

Table-3 shows mean PR interval value in group A on baseline, on $7^{\text {th }}$ day and on $28^{\text {th }}$ day of trial as $0.154 \pm 0.0078$, $0.1632 \pm 0.0065$ and $0.156 \pm 0.0516$ and in group $B$ as $0.165 \pm 0.0123, \quad 0.168 \pm 0.0065$ and $0.1744 \pm 0.0056$ respectively. The change in $p$ value $(p>0.05)$ was not significant in both groups. One-way ANOVA test was used to get $P$ value.

\begin{tabular}{|c|c|c|c|c|}
\hline \multirow{3}{*}{$\begin{array}{c}\text { Group } \\
\text { A }\end{array}$} & $\begin{array}{c}\text { T Wave } \\
\text { Amplitude } \\
\text { (mm) }\end{array}$ & Day 1 & Day 7 & Day 28 \\
\hline & Mean \pm S.D. & $\begin{array}{l}1.333 \pm \\
0.60193\end{array}$ & $\begin{array}{c}0.8 \pm \\
0.60193\end{array}$ & $\begin{array}{c}0.501 \pm \\
0.7379\end{array}$ \\
\hline & Range & $0.5-2$ & $0-1.5$ & $1-1.0$ \\
\hline \multirow{3}{*}{$\begin{array}{c}\text { Group } \\
\text { B }\end{array}$} & $\begin{array}{c}\text { T Wave } \\
\text { Amplitude } \\
\text { (mm) }\end{array}$ & Day 1 & Day 7 & Day 28 \\
\hline & Mean \pm S.D. & $\begin{array}{l}1.98 \pm \\
0.714\end{array}$ & $\begin{array}{l}1.78 \pm \\
0.867\end{array}$ & $\begin{array}{l}2.20 \pm \\
0.736\end{array}$ \\
\hline & Range & $0.5-3.5$ & $0.5-1.5$ & $1-5$ \\
\hline
\end{tabular}

Table- 4 shows the mean values of T-wave amplitude in both the groups at baseline, on $7^{\text {th }}$ day and on $28^{\text {th }}$ day of trial medication. The change in $p$ value $(p>0.05)$ was not significant in both groups.

\begin{tabular}{|c|c|c|c|c|c|c|c|c|c|c|c|c|}
\hline \multirow[t]{2}{*}{ 气 } & \multicolumn{2}{|c|}{ 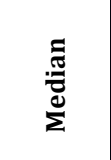 } & \multicolumn{2}{|c|}{ 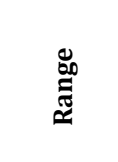 } & \multicolumn{2}{|c|}{ 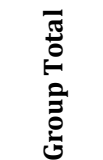 } & \multicolumn{2}{|c|}{ 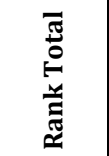 } & \multicolumn{2}{|c|}{ 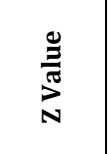 } & \multicolumn{2}{|c|}{$\frac{\stackrel{0}{\Xi}}{\stackrel{\Xi}{\pi}}$} \\
\hline & 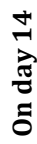 & 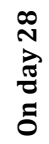 & 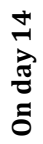 & 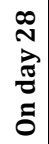 & 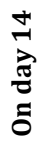 & 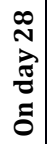 & 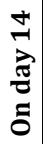 & 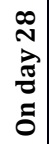 & 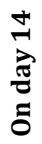 & 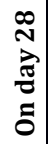 & 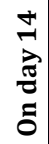 & $\begin{array}{l}\infty \\
\stackrel{\infty}{N} \\
\vec{\pi} \\
\tilde{\sigma} \\
\tilde{0}\end{array}$ \\
\hline$\varangle$ & $\underset{7}{7}$ & $m$ & & $\stackrel{ }{\overrightarrow{1}}$ & 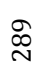 & $\vec{\infty}$ & $\begin{array}{l}0 \\
\text { ते } \\
\tilde{\sigma}\end{array}$ & $\begin{array}{l}0 \\
\dot{0} \\
\stackrel{N}{ }\end{array}$ & & & & \\
\hline & & & & & & & & & 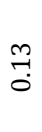 & $\begin{array}{l}\hat{\sigma} \\
\hat{\sigma} \\
-i\end{array}$ & 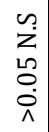 & $\begin{array}{l}0 \\
z \\
2 \\
0 \\
0 \\
1\end{array}$ \\
\hline B & $\exists$ & 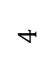 & $\overrightarrow{\text { mे }}$ & ㄱ. & $\stackrel{\widehat{\infty}}{N}$ & $\stackrel{ }{\exists}$ & 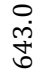 & 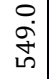 & & & & \\
\hline
\end{tabular}

Table 5. Comparison of Mania Rating Scale (Bech \& Rafaelsen) Score on Day 14 and Day 28 in Group A and B

Table- 5 shows the compassion of improvement in the mania patients according to Mania Rating Scale (Bech \& Refaelsen) score and it was found no significant difference ( $p>0.05$ ) between the two groups (A \& B) on day $14^{\text {th }}$ and day $28^{\text {th }}$ of the treatment. Z-test was used to get $P$ value.

\begin{tabular}{|c|c|c|c|c|}
\hline $\begin{array}{c}\text { Assessment } \\
\text { of Relief }\end{array}$ & \multicolumn{2}{|c|}{$\begin{array}{c}\text { Day 14 } \\
\text { Group A Group B }\end{array}$} & \multicolumn{2}{c|}{$\begin{array}{c}\text { Day 28 } \\
\text { Group A Group B }\end{array}$} \\
\hline $\begin{array}{c}\text { Patient with } \\
\text { No Relief }\end{array}$ & 0 & 0 & 0 & 0 \\
\hline Quarter Relief & 15 & 11 & 1 & 0 \\
\hline Half Relief & 9 & 11 & 7 & 8 \\
\hline $\begin{array}{c}\text { Three-Fourth } \\
\text { Relief }\end{array}$ & 1 & 3 & 12 & 13 \\
\hline Rank total & $\mathbf{5 7 9 . 5}$ & $\mathbf{6 9 5 . 5}$ & $\mathbf{6 4 2 . 0}$ & $\mathbf{6 3 3 . 0}$ \\
\hline Table 6. Attendants' Assessment of Relief on Day 14 and \\
28 in Group A and B \\
\hline
\end{tabular}

Table- 6 shows the attendants' assessment relief report used for comparing the efficacy of Verapamil and Lithium and it was found no significant difference $(p>0.05)$ in both the groups on day $14^{\text {th }}$ and day $28^{\text {th }}$ of the trial medication. T-test was used to get $P$ value.

\section{DISCUSSION}

Verapamil a calcium channel blocker primarily used for cardiovascular disorders has been studied in a few small controlled trials in patients with bipolar mood disorders. The results of few recent studies have shown that verapamil may be tried as an alternative drug in patients who did not respond to lithium or in whom lithium is contraindicated. Verapamil and lithium combination is highly efficacious in treatment of resistant mania patients.[10] Lithium was introduced in 1949, but its clinical use for control of manic excitement gained popularity much later. Some investigator 
reported $70-80 \%$ effectiveness of Lithium in the treatment of acute mania.[11,12] Till date Lithium is the standard drug for the treatment of acute mania. However, it takes 5 to 7 days to start its effect and its dose has to be monitored carefully by keeping the serum Lithium levels within the therapeutic range to avoid its toxic effects.

Our study was conducted to compare the efficacy and ECG changes in patients of acute mania being treated with Lithium carbonate or with verapamil given separately and also to evaluate the cardiac side effects of these two drugs. The median age in group $A$ and group B patients was 30 year and the range of age was 18-50 year and 19-50 year in group A \& $B$ respectively as presented in Table-1. It is in consistence with Giannini et al., 1984 and Garza-Trevino ES et al., 1992. The other characteristics like marital status, male/female ratio, literacy and rural/urban population are similar in both the group as shown in Table-1.

During the trial it was observed a trend of decreasing heart rate on $7^{\text {th }}$ day and $28^{\text {th }}$ day in both the groups as shown in Table-2. But in group B patients the decrease in heart rate on $7^{\text {th }}$ day and $28^{\text {th }}$ day of trial was greater than in the group A patients. The percentage of decrease in heart rate in group $A$ on $7^{\text {th }}$ day and $28^{\text {th }}$ day was $7.2 \%$ and $10.4 \%$ respectively and $10.4 \%$ value was significant $(\mathrm{p}<0.05)$. Whereas in group B patients the percentage of decrease in heart rate was $7.97 \%$ and $19.6 \%$ on 7 th day and $28^{\text {th }}$ day respectively and $19.6 \%$ value was significant $(\mathrm{p}<0.05)$. The decrease in heart rate with verapamil and lithium is due to depression of SA node activity mediated by calcium ion depolarization and increase in effective refractory period of AV node.[13]

Table-3 represents no significant difference $(p>0.05)$ in PR interval of both the groups during the study period.

Table- 4 represents no significant difference $(p>0.05)$ in $T$ wave amplitude of both the groups during the study period. These findings were similar to the findings reported by the investigators in previous studies.[14,15,16,17] The changes observed in $\mathrm{T}$-wave were because of depletion of potassium ions by lithium ions from the cardiac cells.[18] In this study for ethical reasons haloperidol use along with lithium/verapamil medication was permitted to control the inappropriate behavior of acute manic patients. Trihexaphenadyl was also permitted to correct extrapyramidal side effects of haloperidol if they occurred.

Table- 5 shows comparison of efficacy of verapamil and lithium according to Mania Rating Scale (Bech \& Rafaelsen) score of all the patients. There was no significant difference ( $p>0.05$ ) in the both the groups on day $14^{\text {th }}$ and $28^{\text {th }}$ day of the trial.

Patient attendants' assessment relief report Table- 6 shows no significant difference $(p>0.05)$ in both groups on day $14^{\text {th }}$ and day $28^{\text {th }}$ of the trial medication.

In this our study no cardiovascular side effects were observed with verapamil and efficacy wise both the drugs were comparable. Hoschi and Kozeny also reported safe use of verapamil in treatment of bipolar affective disorder.[19]

\section{CONCLUSION}

Verapamil is an effective alternative to lithium for control of acute mania over a short period of 28 days. Verapamil produces greater decrease in the heart rate than that by lithium as shown in the study. Therefore, baseline electrocardiogram should be done before starting verapamil therapy to ascertain previously existing cardiac conduction abnormality in the patients to avoid cardiovascular side effects. It is further suggested that other cardiovascular depressant drugs should be ruled out while using verapamil as an alternative drug for the treatment of acute mania. ECG monitoring should be done during the treatment of acute mania with verapamil to avoid cardiac side effects. Further studies are suggested to compare long term efficacy of verapamil in acute mania by conducting long term studies.

\section{REFERENCES}

[1] Berrios GE. Of mania: introduction (Classic text no. 57). History of Psychiatry 2004;15(57 Pt 1):105-24.

[2] Goldney RD, Fisher LJ, Grande ED, et al. Bipolar I and II disorders in a random and representative Australian population. Aust NZ J Psychiatry 2005;39(8):726-9.

[3] Broadhead J, Jacoby R. Mania in old age: a first prospective study. International Journal of Geriatric Psychiatry 1990;5(4):215-22.

[4] Baldessarini RJ, Stephens JH. Lithium carbonate for affective disorders. I. Clinical pharmacology and toxicology. Archives of General Psychiatry 1970;22(1):72-7.

[5] Schou M, Amdisen A, Jensen ES, et al. Occurrence of goitre during lithium treatment. Brit Med J 1968;3(5620):710-3.

[6] Gianni AJ, Houser WL Jr, Loiselle RH, et al. Antimanic effects of verapamil. American Journal of Psychiatry 1984;141(12):1602-3.

[7] Goodnick PJ. Verapamil prophylaxis in pregnant women with bipolar disorder (letter). Am J Psychiatry 1993;150(10):1560.

[8] Dubovsky SL, Buzan R. The role of calcium channel blockers in the treatment of psychiatric disorders. Central Nervous System Drugs 1995;4(1):47-57.

[9] Amdisen A. Serum lithium determinations for clinical use. Scandinavian Journal of Clinical \& Laboratory Investigation 1967;20(2):104-8.

[10] Malinger AG, Thase ME, Haskett R, et al. Verapamil augmentation of lithium treatment improves outcome in mania unresponsive to lithium alone: preliminary findings and a discussion of therapeutic mechanisms. Bipolar Disord 2008;10(8):856-66.

[11] Maggs R. Treatment of manic illness with lithium carbonate. Br J Psych 1963;109(458):56-65.

[12] Gerbino L, Oleshansky M, Gershon S. Clinical use and mode of action of lithium. In: Lipton MA, DiMascio A, Killan AF, eds. Psychopharmacology: a generation of progress. New York: Raven Press 1978.

[13] Dubovsky SL, Franks RD. Intracellular calcium ions in affective disorders: a review and an hypothesis. Biological Psychiatry 1983;18(7):781-97.

[14] Demers RG, Heninger G. Electrocardiographic changes during lithium treatment. Dis Nerv Syst 1970;31(10):674-9.

[15] Demers RG, Heninger GR. Electrocardiographic Twave changes during lithium carbonate treatment. J Am Med Assoc 1971;218(3):381-6.

[16] Tilkian AG, Schroeder JS, Kao JJ, et al. The cardiovascular effects of lithium in man. A review of the literature. Am J Med 1976;61(5):665-70. 


\section{Jemds.com}

[17] Dumovic P, Burrows GD, Chamberlain K, et al. Effect of therapeutic dosage of lithium on the heart. Br J Clin Pharmacol 1980;9(6):599-604.

[18] Mary PR, Mohandas E. Practical issues in lithium use. Indian J Psychol Med 1995;18:49-60.
Original Research Article

[19] Hoschi C., Kozeny J. Verapamil in affective disorders: a controlled, double-blind study. Biol Psychiatry 1989;25(2):128-40. 